\title{
Intensity of Anthracnose in resistant varieties (PIWI) in the high altitude regions of southern Brazil
}

\author{
Bruno Bonin ${ }^{1}$, Betina de Bem ${ }^{1}$, Alberto Brighenti ${ }^{2}$, Douglas Würz ${ }^{1}$, Ricardo Allebrandt ${ }^{1}$, Emilio Brighenti ${ }^{2}$, \\ Leonardo Araujo ${ }^{2}$, Felipe Augusto Moretti Ferreira Pinto ${ }^{2}$, and Amauri Bogo ${ }^{1}$ \\ ${ }^{1}$ Santa Catarina State University, College of Agriculture and Life Science, Av. Luiz de Camões, 2090, Lages, SC, Brazil \\ ${ }^{2}$ Santa Catarina State Agricultural Research and Rural Extension Agency (EPAGRI), Rua João Araújo Lima, 102, São Joaquim, \\ SC, Brazil
}

\begin{abstract}
The objective of this study was to evaluate the different degrees of tolerance to Anthracnose infection in three PIWI varieties (Cabernet Cortis, Regent and Bronner) compared to the Cabenert Sauvignon variety. The experiment was conducted at EPAGRI Experimental Station, located in the city of São Joaquim,

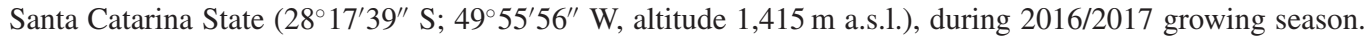
The evaluation of the disease was performed every 15 days, applying a scale of notes, from the onset of symptoms, and lasted for a period of two months, under the condition of infection Natural. The intensity of the disease was compared by epidemiological measures: time to reach maximum disease severity (TRMDS), maximum disease severity (Smax), and area under the severity disease progress curve (AUDSPC). Maturity indices of the varieties were obtained from juice physical-chemical analysis at the harvest. Although the PIWI varieties were resistant to mildew, they were susceptible to anthracnose. Bronner and Cabernet Cortis showed on average the same intensity of disease in the leaves and branches as the Cabernet Sauvignon variety, the Regent variety showed greater susceptibility to the pathogen, differing statistically from the other varieties evaluated.
\end{abstract}

\section{Introduction}

Anthracnose (Elsinoe ampelina) is one of the major fungal diseases in southern Brazil. Rainy springs, fog, relative humidity above $90 \%$ and cold winds are ideal conditions for the development of the disease, its control is usually carried out with systematic applications of fungicides.

Anthracnose, caused by the fungus Ascomycetes Elsinoe ampelina, sexed form of Sphaceloma ampelinum, is one of the main fungal diseases of the grapevine in humid regions. It originates from the European continent and is reported in all the grape producing areas of the world, however, it causes damages in regions of high humidity and high temperature. Due to the characteristic symptom in the berries, this disease is also known as "bird's eye" [1]. Recently, some studies in India and China have associated species of the genus Colletotrichum as causal agent of the anthracnose of the vine [2].

The fungus can infect all the aerial organs of the plant, however, the young tissues are more susceptible. In the leaves, the initial symptoms are small, dark brown, slightly depressed, circular patches. Usually, the lesions are very numerous and can coalesce into a small hole. In the petiole and in the veins the lesions are elongated and cause the unequal development of the foliar tissues, causing the folding and shading of the leaves. In the branches, the disease causes the appearance of cancers with irregular shapes of gray coloration in the center and black borders. In the berries there are circular patches of gray color in the center and black on the edges [3].

Infection can occur at temperatures ranging from $2{ }^{\circ} \mathrm{C}$ to $32^{\circ} \mathrm{C}$, but temperatures between $24^{\circ} \mathrm{C}$ and $26^{\circ} \mathrm{C}$, associated with rainy springs, fogs or locks, relative humidity of over $90 \%$ and cold winds are conditions Ideal for the development of the pathogen and disease. In addition, there is need for at least 12 hours of liquid water on the vegetable tissue. Under favorable conditions, the incubation of the pathogen (period between infection and onset of symptoms) occurs around seven days [1].

The sources of resistance to anthracnose of Asian origin are more promising for genetic improvement purposes, because there is an indication that the inheritance for this character is dominant. Among the Asian species, V. amurensis is most used in the genetic improvement of the vine. Genetic resistance to anthracnose is found in both American and Asian species.

The varieties with resistance genes to mildew and powdery mildew, such as PIWI (Pilzwiderstandsfähige) varieties, are an alternative to reduce the number of conventional fungicide applications and reduce production costs for grapevine planting in southern Brazil. However, few studies have been conducted with anthracnose for PIWI varieties. The objective of this study was to evaluate the different degrees of tolerance to Anthracnose infection in three PIWI varieties (Cabernet Cortis, Regent and Bronner) compared to the Cabenert Sauvignon variety. 
Table 1. Scale of severity notes in the leaves and branches, used to evaluate the anthracnose in vine (PEDRO JUNIOR et al., 1998).

\begin{tabular}{|c|c|}
\hline Nota & Anthracnose intensity \\
\hline $\mathbf{0}$ & 0 \\
\hline $\mathbf{0 , 1}$ & One leaf or branch with injury \\
\hline $\mathbf{0 , 2}$ & Injury in up to 5 leaves or branches \\
\hline $\mathbf{0 , 5}$ & Injury in 6 to 10 leaves or branch \\
\hline $\mathbf{0 , 7}$ & Injury in 11 to 15 leaves or branches \\
\hline $\mathbf{1}$ & 25\% of leaves or branches of the plant with lesions \\
\hline $\mathbf{2}$ & $50 \%$ of leaves or branches of the plant with lesions \\
\hline $\mathbf{3}$ & 75\% of leaves or branches of the plant with lesions \\
\hline $\mathbf{4}$ & 100\% of leaves or branches of the plant with lesions \\
\hline
\end{tabular}

\section{Materials and methods}

The experiments were conducted in São Joaquim Experimental Station (EPAGRI) Vineyards $\left(28^{\circ} 17^{\prime} 39^{\prime \prime} \mathrm{S}\right.$; $49^{\circ} 55^{\prime} 56^{\prime \prime} \mathrm{W}$, altitude $1,415 \mathrm{~m}$ a.s.l), in 2016/2017 cycle. The evaluated varieties were the PIWI varieties (Cabernet Cortis, Regent and Bronner) compared to the Cabenert Sauvignon variety. The vineyard was planted in 2013, the plants were grafted on Paulsen 1103, vines were trained in vertical shooting positioning trellis and spacing $3.0 \times 1.5 \mathrm{~m}$. The meteorological data were obtained from a meteorological station located at vineyard. The daily data of precipitation $(\mathrm{mm})$, air relative humidity $(\%)$ and mean temperature $\left({ }^{\circ} \mathrm{C}\right)$ were obtained from CIRAM (Center of Environmental Resources Information and Hydrometeorology of Santa Catarina).

The evaluation of the disease was performed every 15 days from the onset of symptoms, which occurred on September 25, approximately 15 days after sprouting, and lasted for a period of two and a half months, under the condition of infection Natural. The experiments followed a randomized completed-block design with three replications per variety and all branches and leaves of each plant were evaluated. The severity was evaluated according to the methodology proposed by Pedro Júnior et al. [5] applying the scale of notes (Table 1). The severity data were transformed into a percentage to perform the statistical analysis by the Tukey test $(\mathrm{P}<0.05)$; where $0,0.1,0.2,0.5$ and 0.7 were equivalent to the values $0 \%$, $2.5 \%, 5 \%, 12.5 \%$ and $17.5 \%$, respectively, and the values of 1, 2, 3 and 4 are pre-set in the Table as 25\%, 50\%, $75 \%$ and $100 \%$, respectively.

Anthracnose disease progress curves were constructed and the epidemic were compared using four epidemiological measures: time to reach maximum disease severity (TRMDS), maximum disease severity (Smax), and area under the severity disease progress curve (AUDSPC). AUDPC was calculated according the equation 1.

$$
A U D P C=\sum((Y i+Y i+1) / 2)(t i+1-t i) .
$$

Where: $\mathrm{Y}=$ disease intensity (incidence or severity), $\mathrm{t}=$ unit of time, and $\mathrm{i}=$ cumulative number of evaluations. This area represented thetrapezoidal integration value of severity [6]. Tests for significance were performed using an analysis of variance and post-hoc comparisons performed using a Tukey test $(\alpha=0.05)$. Sis Var software, was used for the data analysis.

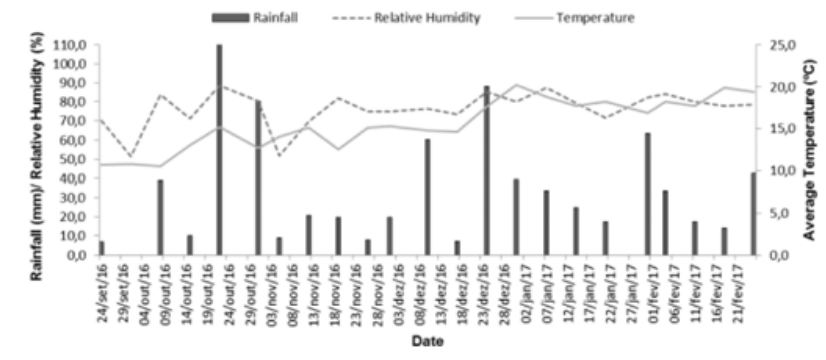

Figure 1. Average monthly accumulated precipitation $(\mathrm{mm})$, air relative humidity $(\%)$ and mean temperature $\left({ }^{\circ} \mathrm{C}\right)$ at Sao Joaquim, Santa Catarina State, Brazil, across 2016/2017 growing season.

At harvest time the productivity were evaluated by clusters weight $\left(\mathrm{kg}\right.$. plant $\left.{ }^{-1}\right)$ of pre-selected plants. The estimated productivity (ton.ha ${ }^{-1}$ ) were obtained by the plant density per hectare and by plants production. At that time, 300 berries of each cultivar were randomly collected and sent to perform physical-chemical and phenolic analysis. From grape must were performed analyses of total soluble solids ( ${ }^{\circ}$ Brix), total acidity $\left(\mathrm{meq} \mathrm{L}^{-1}\right)$ and $\mathrm{pH}$, according to the methodology proposed by OIV [7].

The soluble solids ( ${ }^{\circ}$ Brix) were measured using an optical refractometer (model Instrutherm - RTD-45) with temperature correction. The $\mathrm{pH}$ was measured with a $\mathrm{pH}$ meter (model MP 220 Metler-Toledo). Total acidity was measured by titration method with a $10 \mathrm{~mL}$ aliquot of juice with standardized $0.1 \mathrm{~N} \mathrm{NaOH}$. Total polyphenols content was quantified by the Folin-Ciocalteu method, with absorbance readings at $760 \mathrm{~nm}$ [8].

\section{Results and discussion}

Mean temperature, relative humidity and total precipitation between the first and the last evaluation were, respectively, $13.4{ }^{\circ} \mathrm{C}, 73 \%$ and $429,6 \mathrm{~mm}$ (Fig. 1). The beginning of symptoms appearance occurred at the end of September, in this period October $(277,9 \mathrm{~mm})$ and December $(87,4 \mathrm{~mm})$ were the months with higher rainfall. A combination of frequent rain and sustained humidity, particularly in spring and summer, provided conditions for leaves and branches remain wet, enabling infections by Elsinoe ampelina. Previous studies have shown that for Elsinoe ampelina, temperatures above $15^{\circ} \mathrm{C} \mathrm{C}$ are favorable to the growth of the fungus $[1,3]$.

The spring temperature influences the onset of the disease [8], an occurrence of higher temperatures and higher precipitation in the spring of 2016/2017 cycle provided that as different variants initiated the symptoms at similar times and also resulted in a more homogeneous disease occurrence.

The PIWI varieties took the same time to reach maximum severity of disease (TRMSD) (Table 2), but the variety Cabernet Sauvignon reached the maximum severity of anthracnose (TRMSD) on average 30 days earlier than the resistant varieties, differing statistically from them.

The resistance in plants can be classified in horizontal or vertical by delaying the onset of the epidemic by reducing the initial infections, or making it slower after it is start, by reducing the rate of infection or progress (r) [9]. The Cabernet Cortiz and Regent varieties started first the beginning of the epidemic at September 29. 
Table 2. Characteristics of anthracnose disease, time to reach the maximum disease severity (TRMDS), maximum value of disease severity (Smax) and area under the disease severity (AUDSPC). Disease was evaluated in three tolerant varieties and one susceptible during 2016-2017 growing seasons at Sao Joaquim, Santa Catarina State, Brazil.

\begin{tabular}{|c|c|c|c|}
\hline Variety / Parameter & TRMDS (days) & $\operatorname{Smax}(\%)$ & AUDSPS \\
\hline C.Cortiz & $66 \mathrm{a}$ & $17,5 \mathrm{a}$ & $1041,43 \mathrm{ab}$ \\
\hline Regent & $71 \mathrm{a}$ & $41,66 \mathrm{~b}$ & $1347,09 \mathrm{~b}$ \\
\hline Bronner & $71 \mathrm{a}$ & $15,83 \mathrm{a}$ & $899,28 \mathrm{a}$ \\
\hline C. Sauvignon & $36 \mathrm{~b}$ & $17,5 \mathrm{a}$ & $1073,28 \mathrm{ab}$ \\
\hline Average & 61 & 23,12 & 1090,27 \\
\hline C.V(\%) & 16,39 & 32,83 & 24,40 \\
\hline
\end{tabular}

C.V. - Coefficient of variance. *Means followed by the same letter in the same row are not significant different (Tukey test, $\mathrm{P}<0.05$ ). a Percentage of disease by a diagrammatic scale of Pedro Junior et al. [5]. b Area calculated by trapezoidal integration value according to Campbell and Madden [6].

The Regent variety presented the maximum severity (Smax) (Table 2), 41,66\% on average, superior from other varieties, differing statistically from them. Cabernet Cortiz, Bronner and Cabernet Sauvignon, presented statistically, the same maximum value of disease severity.

In the comparative epidemiology, the parameter used to compare different degrees of susceptibility of plants to pathogens is the disease progress rate. Quantification of a variable that expresses the severity (intensity) of the disease is important to describe the progress of epidemics over time and its relationship with the weather or with different forms of management [10].

In comparative epidemiology, the parameter used to differentiate the susceptibility of plants under different conditions is the rate of disease progression. The quantification of a variable that expresses the incidence and severity (intensity) of the disease is important to describe the progress of epidemics over time and their relation to the climate or with different forms of management [11].

There were significant differences between the varieties by area under the curve progress severity of disease (AUDSPC) (Table 2). There was a significant increase in AUDSPC of Regent variety (Fig. 2). The AUDSPS of Regent variety with a total 1347,09 , was higher than the average of the curves of the disease of Cabernet Cortiz $(1041,43)$ Bronner $(899,28)$ and Cabernet Sauvignon (1073,27).

The primary infection of anthracnose occurred from late September to early October, approximately four weeks after sprouting. Leaves that were not infected in the first four weeks remained anthracnose free and the most severe epidemics occurred at times of short rainfall intervals [12]. In the same way as reported above, in the present study infections started soon after sprouting, but the disease also occurred in the older leaves, but not as in the young leaves.

A significant increase in disease of intensity occurred in Regent variety, on the 70nd day after the first evaluation (Fig. 2). Possibly, the increasing intensity of disease is related to the increase in temperatures and rainfall in the region, and the more susceptibility from this variety to anthracnose.

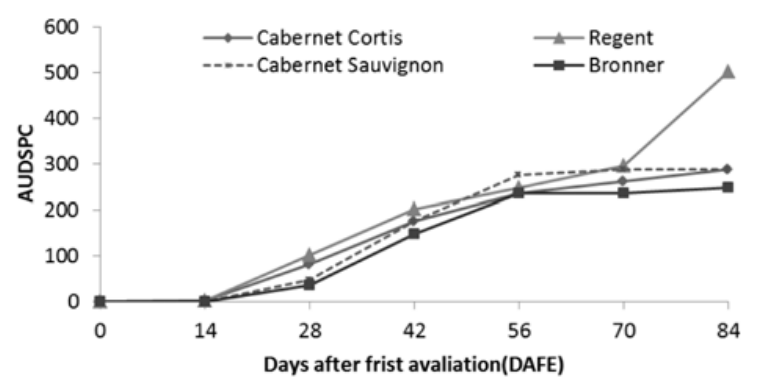

Figure 2. Antrachnose disease progress curves for area under disease severity (AUDSPC) for PIWI varieties Cabernet Cortiz, Regent and Bronner and for Cabernet Sauvignon variety during 2016-2017 growing season in Sao Joaquim, Santa Catarina State, Brazil.

Table 3. Maturity indices for Cabernet Coriz, Regent, Bronner and Cabernet Sauvignon obtained from juice physical-chemical analysis at the harvest on 2016-2017 growing season, in Sao Joaquim, Santa Catarina State, Brazil.

\begin{tabular}{|c|c|c|c|c|}
\hline Variety & $\begin{array}{c}\text { TSS } \\
\left({ }^{\circ} \text { Brix }\right)\end{array}$ & $\begin{array}{c}\text { TA } \\
\left(\text { meq L }^{-\mathbf{1}}\right)\end{array}$ & pH & $\begin{array}{c}\text { Total Polyphenols } \\
\left(\mathbf{m g ~ L}^{-\mathbf{1}}\right)\end{array}$ \\
\hline C. Cortiz & 23,9 & 104,16 & 2,98 & 2045,8 \\
\hline Regent & 19,6 & 69,4 & 3,45 & 4048,4 \\
\hline Bronner & 20,5 & 100,3 & 2,87 & 256,9 \\
\hline C. Sauvignom & 20,6 & 160,3 & 2,9 & 1764,3 \\
\hline
\end{tabular}

Maturity indices obtained by physical-chemical analysis of grape juice from different varieties at harvest, was appropriate for the elaboration of high quality wines in the season 2016/2017 (Table 3). Appropriate parameters for winemaking are $\mathrm{pH}$ between 2.9 and 3.6; titratable acidity above $100 \mathrm{meq} \mathrm{L}^{-1}$, total soluble solids above $20^{\circ}$ Brix.

The white variety Bronner presented a quantity of polyphenols suitable for this type of grape. Polyphenols have the function of protecting plants from physical (such as the sun UV radiation) and biological (fungi, viruses, bacteria) attacks. Polyphenols from the group of non-flavonoids, as the stilbenes are phytoalexins, i.e., compounds synthesized by vine in response to a stressful situation, such as pathogen attack [12]. The high contents of polyphenols in red varieties, especially on Regent berries are a good alternative for the elaboration of red wines with complexity and quality.

\section{Conclusion}

Although the PIWI varieties were resistant to mildew, they were susceptible to anthracnose. Bronner and Cabernet Cortis showed on average the same intensity of disease in the leaves and branches as the Cabernet Sauvignon variety, which presented $17.5 \%$ of average severity.

The Cabernet Cortis variety had an average severity of $17.5 \%$, and Bronner presented $15.6 \%$. The Regent variety showed greater susceptibility to the pathogen, differing statistically from the other varieties evaluated, with an average of $41.6 \%$ of leaf and branch severity.

Therefore, the mildew resistant varieties evaluated had the same degree or greater susceptibility to Anthracnose compared to the Cabernet Sauvignon variety under the climatic conditions of southern Brazil. 


\section{References}

[1] L. Amorim.; H. Kuniyuki, Diseases of the vine. (Ed.) Manual of phytopathology: diseases of cultivated plants. 3.ed. São Paulo: Agronômica Ceres, 1997 2, p. 736-757

[2] S. Sawant, Indu et al. Emergence of Colletotrichum gloeosporioides sensu lato as the dominant pathogen of anthracnose disease of grapes in India as evidenced by cultural, morphological and molecular data. Australasian Plant Pathology 41(5), p. 493-504 (2012)

[3] P.J. Brook, Epidemiology of grapevine anthracnose, caused by Elsinoe ampelina. New Zealand Journal of Agricultural Research (1973)

[4] M. A. Ellis, \& O. Erincik, Anthracnose of Grape. The Ohio State University Extension (2008)

[5] M. J, Pedro Júnior; I.J. Ribeiro; A. Martins, F.P. Microclimate conditioning by the removal of leaves and occurrence of anthracnose, downy mildew and 49 leaf spot on the 'Niagara Rosada' vine. Summa Phytopathologica, Jaguariúna 24(2), p. 151-156 (1998)

[6] C.L. Campbell, L.V. Madden. Introduction to Plant Disease Epidemiology (Wiley, New York, 532, 1990)
[7] OIV - Organization Internationale de la Vigne et du Vin. Compendium of International Methods of Wine and Must Analysis (OIV, Paris, 504, 2009)

[8] C.R.C. Buffara, F. Angelotti, F.A. Vieira, A. Bogo, D.J. Tessmann, B.P. de Bem. Elaboration and validation of a diagrammatic scale to assess downy mildew severity in grapevine. Cienc. Rural 44, 13841391 (2014)

[9] J.E. Van der Plank. Plant Diseases: epidemics and control (Academic Press, New York, 349, 1963)

[10] M.B. Spósito, Temporal and spatial dynamics of the black spot (Guignardia citricarpa) and quantification of the damage caused to the citrus crop. Thesis (Doctorate). School of Agriculture Luiz de Queiroz, Piracicaba (2003)

[11] P.J. Brook Epidemiology of grapevine anthracnose and downy mildew in Auckland. New Zealand vineyards, New Zealand Journal of Horticulture Science 20, 37-49 (1992)

[12] N.F.S. Vaccari, M.C.H. Soccol, G.M. Ide. Phenolic compounds in wines and their antioxidant effects in disease prevention. Revista de Ciências Agroveterinárias 8, 710-83 (2009) 